\title{
Chemistry Department of Karolinska Mediko-kirurgiska Institutet in Stockholm 1810—1960
}

\author{
J. E R I K J O R E S
}

Chemistry Department II, Karolinska Institutet, Stockholm, Sweden

Karolinska Institutet, the State Medical School in Stockholm, this year celebrates its 150th Anniversary. With its forty-five professors, twenty-two associate professors, 250 assistant teachers and about 1000 undergraduates it is at present about twice as large as any of the other medical faculties of Sweden. It is an independent medical school with otherwise the same academic status as the medical faculties of the universities at Uppsala, Lund, Gothenburg and Umeå. Its activities, however, have in the past and in recent times as well extended considerably beyond the grounds of the purely medical sciences, particularly in the field of chemistry.

It is unique among the medical schools of Europe in that, from the beginning, chemistry was taught to the medical students by a full time professor. Furthermore, this professor happened to be Jöns Jacob Berzelius (1779-1848). In 1802 he began lecturing on chemistry to the medical profession of Stockholm. In 1807 he was appointed professor of medicine and pharmacy at the Surgical School of the Medical Board and from 1813 professor of chemistry and pharmacy at the new Medical School, Karolinska Institutet, erected in 1810 in Stockholm.

In one respect the teaching system of the medical faculties in Sweden including Karolinska Institutet differs from that prevailing outside of Scandinavia. Complete medical education is as a rule a prerequisite for an appointment as teacher at a medical school, a system introduced already in Berzelius' days. He himself, Olof Hammarsten and Torsten Thunberg were physicians like all the present members of the teachers' staff with only one exception amongst 200 chairs, including the chairs of chemistry, physiology, pharmacology, bacteriology, anatomy and histology.

On this occasion it may not be out of place to review shortly the main scientific achievements reached at the Chemistry Department of Karolinska Institutet. It is quite remarkable that before the time of spectral analysis no less than 9 new elements were discovered within a short space of time at one and the same institute. 
Few chemists have been as successful in their work as Berzelius. His influence upon events in the field of chemistry rivalled that of Linnaeus in botany. In 1813 he introduced the chemical nomenclature in use today, applying the first letter or letters of the Latin name of the elements as their symbols. He determined the combining weights of 45 of the 49 elements then known. He himself discovered cerium, selenium and thorium, and his pupils Arfwedson and Sefström lithium and vanadium, respectively. His co-worker and successor, C. G. Mosander, discovered lanthanum, didymium, erbium and terbium, the two latter from the famous yttria earth - named after the small village Ytterby in the archipelago of Stockholm. The concepts of isomerism and catalysis were created by him. His textbook in chemistry was a standard work of its time, the fifth German edition of which appeared in 5 volumes between 1843 and 1848, with no fewer than 4650 pages. His animal chemistry of 1806 and 1830 and his annual reviews of the progress of chemistry, physics and mineralogy for the years $1821-1848$ were highly appreciated by the contemporary scientific world. Here only a short reference is made to the literature dealing with Berzelius *. His successor Mosander is presented in a separate paper.

Count Karl Axel Hampus Mörner, professor of chemistry and pharmacy between 1884 and 1917, was a prominent personality. In 1897 he discovered myoglobin, a substance which Hugo Theorell crystallized in 1932 in Mörner's old laboratory at Karolinska Institutet. In 1899 Mörner demonstrated that cystine, found by Wollaston in 1810 in a urinary calculus, is an ordinary amino acid, occurring in most proteins, and very abundantly in keratin. As Dean of the faculty 1897-1917 he helped to draw up the Articles of the Nobel Foundation and was head of the Nobel Committee for Physiology and Medicine from 1901 to 1917.

The research activities of the Chemistry Department were greatly expanded under the leadership of Einar Hammarsten (associate professor of chemistry and pharmacy 1918-1928; professor 1928-1957). About 1920 he showed that not only guanylic acid but also pyrimidine pentose nucleotides do occur in the pancreas. In his doctor's dissertation of 1924 he demonstrated that the laws of the osmotic pressure do not apply to the salts of thymonucleic acid and similar high molecular acids, the cations being devoid of osmotic effects. This phenomenon enables thymonucleic acid to be stored in high concentration in

* H. G. Söderbaum: Jac Berzelius, Levnadsteckning (in Swedish) I and II 1929, III 1931. Edited by the Royal Swedish Academy of Sciences. Almqvist \& Wiksell, Uppsala. I-III about 1600 pages.

Arne Holmberg: Biografi över J. J. Berzelius utgiven av K. Sv. Vetenskapsakademien; I Printed material written by and about Berzelius 1933; Supplem. 1936 and 1953; II Manuscripts 1936; Supplem. 1953.

Jöns Jacob Berzelius: Autobiographical notes (in Swedish), published by the Royal Swedish Academy of Sciences through H. G. Söderbaum 1901. Edit. Norstedt \& Söner, Stockholm. English translation by Olof Larsell, Professor of Anatomy, University of Oregon, Med. School, Portland. 1934. Edit. Williams \& Wilkins, Baltimore.

Harold Hartley: The place of Berzelius in the history of chemistry. Lecture delivered at the meeting of the Swedish Academy of Sciences September 22, 1948. Levnadsteckningar över $K$. S $v$. Vetenskapsakademiens ledamöter, No. 135. Almqvist \& Wiksell, Uppsala 1948.

Arne Fredga: Jöns Jacob Berzelius. Minnesteckning föredragen vid minnesfesten över Berzelius i Stockholms Stadshus den 20 september 1948. Levnadsteckningar över $K$. Sv. Vetenskapsakademiens ledamöter, No. 134. Almqvist \& Wiksell, 1948. 
the cell nuclei, as also the heparin in the granules of the mast cells, without osmotic breakdown of the nuclear or granular membranes due to uptake of water. Hammarsten's institute was at that time one of the few research centres devoted to the study of nucleic acid chemistry. With the advent in later years of the isotope technique for the study of the metabolism of purines and pyrimidines his institute was well equipped to enter the new field.

In the course of the years, under Hammarsten's leadership, several independent research institutes were erected closely connected to his own department: the Biochemistry Department of the Nobel Institute of Medicine under Hugo Theorell (professor of biochemistry 1937 -), the Institute of Cell Research under Torbjörn Caspersson (professor of cell research 1944-), and the Institute of Medical Physics under Arne Engström (professor of medical physics 1952-).

Theorell's work from 1934 on the isolation of Warburg's yellow respiratory enzyme by means of an electrophoresis apparatus, designed by Theorell himself, his demonstration of phosphoric acid in its prosthetic group and the separation of the co-enzyme and apo-enzyme and their reunion into an active enzyme, and the crystallization of the enzyme, aroused great attention. In 1934 Caspersson introduced ultra-violet microscopy into histology, thus enabling the morphological processes to be studied without fixation or destruction of the tissues.

In the 1930's Hammarsten and Gunnar Agren, in collaboration with Henrik Lagerlöf and Hilding Berglund, made fundamental studies on the intestinal hormone secretin. A secretin test for the pancreatic function was elaborated.

In 1935 Erik Jorpes (associate professor of chemistry and pharmacy 1919-1947; professor of medical chemistry 1947-) found heparin to be a highly esterified sulfo-mucopolysaccharide. A number of Swedish clinicians headed by Clarence Crafoord and Gunnar Bauer then started to use heparin as a remedy against thrombosis, simultaneously with Charles Best, Gordon Murray and their co-workers of the University of Toronto. In 1937 Jorpes and Olof Wilander in collaboration with the histologist Hjalmar Holmgren discovered that the metachromatic granules of the tissue mast cells of Ehrlich consist of heparin. An overwhelming literature is now dealing with the mast cells as well as with the therapeutic and prophylactic use of anticoagulants against thrombosis.

In recent years Jorpes and Viktor Mutt purified cholecystokinin and secretin. The latter was found to have an extremely high biological activity.

The extended study of heparin and of its interference in the coagulation mechanism resulted in new findings in the coagulation field. Thus, Margareta and Birger Blombäck succeeded in 1956 in elaborating a new technique of preparing fibrinogen which made this plasma protein more easily accessible for use in surgery and obstetrics. With the same technique a preparation can be obtained, containing the antihemophilic globilin, coagulation factor VIII, now in use as a specific therapeutic agent in hemophilia A.

Per Edman initiated his studies on proteins at the Chemistry Department with his thesis of 1945 on the purification of hypertensin. During his subsequent stay at the University of Lund they were followed up with his invention of a new ingenious technique for the determination of $\mathrm{N}$-terminal amino acids in proteins and peptides and for the determination of the sequence of the amino acids in a peptide chain.

Acta Chem. Scand. 14 (1960) No. 8 
Likewise Torsten Teorell, professor of physiology, Uppsala, got his education under Hammarsten.

Robin Fahraeus, later professor of pathology at Uppsala, performed at the Chemsistry Department around 1920 the experimental work in connection with his discovery of the erythrocyte suspension stability test, which later became an extremely important diagnostic tool in medicine.

As previously pointed out complete medical education is as a rule a prerequisite for an appointment as teacher at a medical school in Sweden. Along the same line the chemical laboratories for clinical pathology are run by medical men, trained in biochemistry at the medical faculties; thus Greta Hammarsten, Kjell Agner, Bertil Josephson, Bo Norberg, Bertil Swedin and Ingemar Jungner in Stockholm, Olof Wilander in Örebro, Carl-Olof Oldfeldt in Linköping and Gunnar Jungner in Gothenburg got their postgraduate training at the Chemistry Department of Karolinska Institutet. During the last 30 years 37 such laboratories attached to larger clinical centres have been erected in Sweden, not less than 7 in the City of Stockholm, a trend in the recent development of our hospital system which pays due attention to the importance of biochemistry for medicine. The head of a clinical laboratory attached to a university clinic has teaching obligations as well. This system enables the doctors to have in their vicinity laboratory people speaking their own language, helping them in interpreting the chemical tests and discussing diagnostic and therapeutic problems. 